\title{
Women Candidates for Political Office in the US in the Twenties
}

\author{
Antonio Daniel Juan Rubio, Isabel Maria Garcia Conesa \\ Centro Universitario de la Defensa de San Javier, San Javier, Spain \\ Email: danirubio71@hotmail.com
}

Received 26 September 2015; accepted 5 December 2015; published 10 December 2015

Copyright (C) 2015 by authors and Scientific Research Publishing Inc.

This work is licensed under the Creative Commons Attribution International License (CC BY). http://creativecommons.org/licenses/by/4.0/

C) (i) Open Access

\begin{abstract}
The US politics changed significantly with the presence of women in the same and their entrance in all areas of government, something just unthinkable a decade ago. The political culture of the American society changed dramatically during and since the twenties. The different political interests as well as the style introduced in politics by the first women legislators made citizens change their formed image of politics and politicians. Women were breaking into the political landscape with more strength, but what we were quite certain about was the arduous task that women had to face in the twenties in order to reach relevant public or political office. Perhaps the most noticeable changes had to do with the impact that women voters had on the electoral process itself, in the places where they voted, their behaviour, and above all, the meaning given to the voting process. Therefore, the main objective of this detailed study is on the political activity of women from the twenties. Women have been the backbone in a process by which federal and local governments assumed greater responsibility for the welfare of their fellow citizens. The presence of women in Congress made possible a transformation of party politics in the XIX century to the policy based on interest groups and candidates that characterised both the XX and XXI centuries. Henceforth, the presence of women in American politics had already been noted in the twenties with women in the positions of state governors, city mayors and representatives of the various state legislatures. Quite often though, women have been involved in politics with the aim of promoting various causes, especially those related to family matters or to the health of the local community, putting it ahead of their own personal interests.
\end{abstract}

\section{Keywords}

US Politics, Women in Politics, Women in Political Office, Political Struggle

\section{Introduction}

The political culture of the American society changed dramatically during and since the twenties. But probably 
the perception of women active in politics along this decade was a bit different as still perceiving the sharp boundaries which shaped an appropriate behavior as well as the political work for both men and women.

Gradually, women were breaking into the political landscape with more strength, but what we were quite certain about was the arduous task that women had to face in the twenties in order to reach relevant public or political office. In fact, it was not until the thirties that we would come across the first featured cases in the cabinet of the nation, although it would also be fair to reckon that the very first cases of women mayors, judges or members of Congress happened in the twenties.

Henceforth, the presence of women in American politics had already been noted in the twenties with women in the positions of state governors (Wyoming, Texas), city mayors and representatives of the various state legislatures. We had even met the case of two women who had opted for the presidential race: Victoria Woodhull in 1872 and Belva Lockwood in 1884 and in 1888.

As women had historically been barred from politics and had been legally excluded from voting until 1920, this prevented them largely from standing for election due to their exclusion from the powerful circles of the main political parties. Quite often though, women have been involved in politics with the aim of promoting various causes, especially those related to family matters or to the health of the local community, putting it ahead of their own personal interests.

And so we come to the 1920s where we find the appearance of the first politically active women. This fact had a clear neat reflection in their presence in the US Congress for the first time in history, as we shall give further detail along this article. But let us add that the topic of cultural confrontation with women at its height did not cease with their active introduction in the politics of the country but, rather on the contrary, it increased further on and even today it remains quite latent in some major US media.

As referred, we can reflect the case of the prestigious newspaper "International Herald Tribune", which recently published an article that reflects the cultural struggle with the issue of women in its epicenter, not presenting it as a confrontation between men and women, but rather through the main ideological lines of the two major parties. To that end, the representative of the state of Washington, Christine Rogers referred to in an article in the following terms: "The Democrats are manipulating the war against women to distract the national attention from the really important issues" [1].

This political presence has culminated in the first nomination of a woman to the post of vice-president in the figure of Geraldine Ferraro [2], and arriving up to the appointment of Sarah Palin as vice-president by the Republican Party in the presidential elections in 2008, in which the democrat Barrack Obama, the first black president in the history of the US, won by a landslide margin. In the same elections, we find, on the Democratic side, the figure of Hillary Clinton, who served as Secretary of State. It should be pointed out that, according to the US Constitution, Clinton is the second in the line of the succession to the presidency, just behind the vice-president.

Throughout this paper we shall examine the role of women in American politics from the decade of the twenties. We will begin by considering their inclusion in the two major political parties before actually moving on to the neat review of their insertion in the country's different political bodies at all its levels (local, state, and federal). Finally, we will study the difficulties encountered by the first women in politics and their most significant achievements and impacts obtained.

\section{Women Political Candidates}

The idea that women could aspire to political office was not a primary objective of heated debates for and against with regard to women's suffrage. Quoting reporter Lucy K. Miller: "We, women, do not deceive ourselves thinking that we are political because men have more experience. So they can always surpass us in political strategy" [3].

In a recent book on the election of women to relevant political office, the authors Robert Darcy, Susan Welch and Janet Clark, concluded with the following statement: "Examining the thinking of political theorists, the historical background of our current political system and the female suffrage movement, the idea that women would occupy a political office was simply not contemplated or imagined” [4].

Even the professor of American history Nancy Cott [5] herself coincided with them in stating that the suffragists rarely focused on the issue of having the election of women to political office as a priority. This statement confirmed the reality that including women in political office was not a central objective of the suffragist movement. In addition, an article published in the magazine "Woman Citizen" [6] assured her readers that while 
some suffragette leaders had been proposed to relevant political office, most of them had no desire to run in for political office.

As this last statement clearly shows, the suffragettes sometimes discussed about the possibilities that some women entered politics as strong candidates. Hence they concluded that if women's suffrage led them directly to state and national legislatures, this fact would significantly improve the legislation because the interests of both women and children would be better represented.

Some other suffragettes recalled the attention upon the fact that the right to vote meant the right to be voted and elected. Sophonisba Breckinridge [7], assistant professor of social economy, described three arguments used in the days of struggle with respect to women and public office: firstly, that there were some posts for which women were especially gifted; secondly, the support to the admission of women to the legislative bodies of the states; and thirdly, it was argued that this was another way to increase job opportunities for women.

And it is certain that during the twenties, as a result of their introduction into the labor market as a direct consequence of the world wars, women were chosen to public and political office in large quantities. This new trend was extensively examined and discussed by political analysts, women writers, and especially in the pages of the feminist magazine "Woman Citizen".

In the early twentieth century, women chose and managed several public positions in politics, and even before, some women had already been appointed to various boards state-wide. According to Helen L. Sumner [8], a researcher on the history of labor in the US, some women were put forward to different positions in state charities, public health, or penitentiary institutions. During the first decades of the twentieth century, mostly twenties and thirties, one of the most shocking events in American politics was the increase of women who carried out elected posts. Although women typically faced many difficulties in order to achieve political success, their luck changed from those times onwards.

And this is clearly demonstrated in the increase of professional research on gender and public office. The research has primarily been focused on issues such as: the difference in legislative outcomes as a result of the increased number of women legislators (Saint-Germain, 1989; Thomas \& Welch, 1991; Reingold, 1992); the role of gender (Darcy, Welch \& Clark, 1987; Rule, 1990); institutional characteristics of the political system and the impact of women candidates to the legislatures (Squire, 1992; Matland \& Brown, 1992); or the greater number of women as legislative leaders (Jewell \& Wicker, 1993).

\subsection{Women Governors and State Officials}

During the twenties, there were two women governors to whom much publicity was given during the period. Incidentally enough, they were both wives of men who had previously served as governors: Nellie Tayloe Ross and Miriam "Ma” Fergusson.

Nellie Tayloe Ross [9] took over the role of governor of the state of Wyoming in June 1925, three months after her husband's death, the former governor. Ross only served for one term and lost her fight for re-election to the next. Miriam "Ma" Fergusson [10] was elected by the state of Texas as the successor of her deceased husband, also the former governor, who had previously been tried in court and therefore could not present himself to the election.

But if both remain noteworthy, coinciding in the succession of their husbands, they were not the only ones. Across the country, a number of women were elected to various state offices. In the state of New Mexico in 1920, for instance, the governor appointed several women in all state boards, up to having a woman as Deputy Secretary of State.

According to American historian Joan M. Jensen, women took control of the board of health [11]. It is quite remarkable that all these women served in western states of the country, being the first to open their doors to the entrance of women in politics because of the fact that they sought to increase their population attracting people from the east part of the country.

Then, in 1929, the "New York Times" published an exhaustive report by Ida C. Clark [12] with the number of women serving in various official positions state-wide. The report recounted the following positions appreciated: 2 State Treasurers, 1 Secretary of State (Gladys Pyle, Republican by South Dakota), 3 Public School Supervisors, 1 Auditor, 1 member of the State Railroad Commission, and 1 woman in the Supreme Court of Ohio (Florence Allen). They all belonged to Midwest states for the reasons already put forward.

In fact, in 1930, a total of 13 women had held the post of Secretary of State across the country, and even 10 
states already had women as State Supervisor of Public Education in the twenties. This was something which up to that date had not happened anywhere in the country. But in contrast, following historian Sophonisba Breckinridge [13], no woman had served as an Attorney General along the decade.

In addition, the list was completed with 4 women elected secretaries of their respective State Supreme Courts, 1 woman as a Reporter of the State Supreme Court of Indiana, and 8 women who served as State Councilors. The report concludes that in 1928, over a thousand women had been elected to various state public offices across the nation.

\subsection{Women State Legislators}

Although women had exceptionally served in state legislatures even before the ratification of women's suffrage, the number of women who aspired and got seats in the various legislatures increased dramatically in the twenties, as the author Dorothy Moncure [14] reflected in an article published in 1929.

Thus, in 1931, the state of Louisiana became the only state in the entire country to elect a woman legislator. The first African-American woman to serve in a state legislature, E. Howard Harper of West Virginia, was named to succeed her husband in 1928. Once again, the western states topped the list in number of women elected to the various legislatures. For example, Connecticut chose 47 women legislators and the state of New Hampshire moved from 3 in 1921 to 17 in 1931. When Sophonisba carried out her research in 1933, more than 320 women had served in the various state legislatures.

By contrast, the southern states fell quite behind in the number of women who had and obtained a legislative post. For example, only 1 woman served in the state legislature of Alabama in 1923, another in 1948, and there were no more female representation up to the seventies.

According to the research conducted by judge Florence E. Allen [15], the number of women in state posts continued to increase slowly. So, in 1946, there were 234 women in the state legislatures of 39 states and more than 1,500 women in executive positions in state governments.

Although there is no record available of the number of women presenting to various state legislatures during the twenties, the magazine "Woman Citizen" made an attempt to identify a list of all candidates in that period. Thus, in November 1922, it conducted a study by all states with the names of women candidates at both state and national positions.

In response, 37 states sent their listings with the result of 179 women nominated to the various state legislatures. Some states provided detailed reports of the various candidates for several years. For example, Connecticut had 34 women presenting to the House of Representatives (28 Democrats, 3 Republicans, 1 Socialist, and 2 Independents). All Republican women were successful while only 1 Democrat did it. As Florence Allen stated, if 27 women presented in 1922 being 7 elected (6 of them Republican), in 192434 women presented being 15 chosen, all of them Republican.

Moreover, another significant state, as New Jersey, also gave minute details about the candidates presented to the different election. So, historian Felice D. Gordon [16] noted that 7 women presented in 1920 in the state elections, increasing to 13 in 1922, 15 in 1924, and up to 18 in 1928.

\subsection{Women in Local and Municipal Offices}

In a lower ladder, we can guess that the various local governments had fewer barriers to women's participation in advisory bodies. For different reasons, like analyst Mildred Adams argues, women who opted for local posts (country commissioners, city councilors, mayors, etc.) seemed to voters less threatening for the male dominating elites and less dangerous than women presenting to Congress or state legislatures.

The explanations for this strange phenomenon lie, firstly in the fact that the involvement of women in these positions usually represented only a part-time job close to home and family. Therefore, they could easily reconcile their work and family obligations. And secondly, working in the county or city government was considered an extension of women's capabilities.

These positions were independent in practice, which meant that it was easier for women with little or no political experience to apply for and to occupy them. As Sophonisba Breckinridge said: "The competition for power is not so great in that parcel of politics" [17].

Or rather, as the historians Darcy, Welch and Clark argued: "The style of local government differed from the other levels of government. It was voluntary, and decisions were typically reached by consensus rather than by 
conflict. In many ways, the style of local politics was a mere extension of the personal relationships rather than the policy we have come across at state or national level” [18].

Historian Sophonisba Breckinridge agreed with these assessments when in a study on the situation of women outside the home, she found that it was the jurisdiction where the evidence of the activity of the women was more evident. As she stated: "There have been women mayors in city councils, city employees, and in the county councils. Women in politics progress faster at home rather than in the larger policy areas" [19].

Peering the positions that women held provides us with a clearer notion of what positions were considered acceptable for women to qualify for the same. In other words, this information provides us with the perception to where the boundaries of gender in politics redrew. The women's traditional concern for children and education paved the way to serve as municipal officials in education.

For example, in the state of Colorado, a woman was elected to the post of State Superintendent of Public Instruction a year after being granted the suffrage to women nationwide. Another significant example is provided by the state of New Mexico where 2 women had been elected as State Supervisory in Education in 1908, perhaps being the first in the country. In the 1920 elections, women submitted to this post in 20 of the 28 counties. The final result was that 19 women were elected to that position.

The Arizona state elected women to that position in nine of the twelve counties in 1922, and the state of Colorado in fifty of the sixty-three counties. By contrast, in the state of Rhode Island only two of the thirty-nine school supervisors were women in the mid-thirties, as suggested by analyst Charles E. Merriam [20].

Most women mentioned earlier in municipal positions were in the position of supervisor of education in all the states analyzed. For example, in the state of Iowa more than half were female school supervisors from 1921 to 1931. During the twenties, women in Iowa made inroads in other city and local positions.

According to Avis M. Saint [21], while 38\% of the county archivists were women in 1921, in 1931 that figure rose to $56 \%$. At the same time, they joined in posts such as the following: county auditors (eleven), legal secretaries (eight), and municipal treasurers (six).

Even in other states, the county archivist position was considered as a suitable position for women, in addition to the educational supervisor one. Therefore, the state of Texas had 109 women archivists in 1930, but only 47 supervisors. In the state of Pennsylvania, where there were very few women who occupied any local or municipal office in the decade, women held positions of county auditors in 1931 with a presence of 11 women in the post.

Several contemporary newspapers echoed the growing number of women in various local and municipal positions in several small towns in states like Iowa, Oregon, New York, Wyoming, Ohio, Colorado, North Dakota, and Michigan, in the twenties. In most cases, women had organized by themselves because mayors and local government bodies had abdicated their responsibilities so citizenship needed and required both physical and moral cleanliness. Women, therefore, often served for years after the negative publicity had ceased.

However, a study led by Randolph Huus [22] in 1930 in the state of Cleveland, found a link between offices and positions that were held by women: a state senator, three members of the state legislature, a council member, and eighty local and municipal posts. In short, as the historian Martin Gruberg [23] said in his study of women in elected office, what it is clear from all these fragmented data in the lower level of local government is that local and municipal governments quickly opened their doors to women during the twenties.

\section{The Difficulties of the First Women in Politics}

Even before women could opt for public office, they had to face off, in countless times, legal barriers. And even before getting the job, they often had to face skeptical voters, whether not openly hostile, both men and women. In the years preceding the suffrage, some assumed, and others feared, that getting the vote would automatically grant women the right to hold public and political office. And yet after suffrage, this belief persisted among some women.

Anna Dickie Olesen, a Minnesota Senate candidate, stated the following in a newspaper article: "I did not have to apologize for being a candidate for the US Senate. The highest authority in the land gave me the right to vote and therefore to be eligible for public office" [24].

The political parties, eager to attract women voters, also seemed to support this argument. As soon as the XIX Amendment was ratified in 1920, the main political parties made plans to nominate women to public office in different states as a way to attract voters. But just as quickly, these actions were severed. That strong resistance 
to change that took place in society was reflected in the strong opposition that the first female candidates had to face to enter politics.

As a proof of this, we can emphasize the fact that the then Attorney General of Missouri ruled in 1920 that the four women candidates for the state legislature were not qualified to serve in the position. Similarly, the Arkansas Attorney General declared that women were not likely to be elected to hold public office. According to this school of thought, the Secretary of State refused to accept the nomination of a woman as a Republican candidate for the post of superintendent of public education in the state of Arkansas.

On the contrary, the state of Wisconsin, which passed on an equal rights law in 1921 made sure to mention the right of women to hold political office. Columnist Mabel Search put it as follows: "Women shall have the same rights and privileges under the law than men in the exercise of suffrage, freedom of contract, choice of residence for voting, and the display of public office” [25].

Other examples were formed by the state of New Mexico, which changed its constitution in 1921 to allow women to hold public office, and the state of Iowa that launched an amendment to its constitution in 1926, removing the word "male" as a prior requirement to attend any public office. As the political analyst Martin Gruberg [26] said, other states followed the example of these two in the twenties, often in response to the pressure from the "League of Women Voters" (LWV) and other women's organizations.

However, the desire of the main political parties to curry favor with female voters often seemed to exceed legal ties. Although the Attorney General of Massachusetts, like some others, found that women were not eligible for public office in the elections of 1920, the Democrats nominated a woman for the post of treasurer of the state without any protest from any side.

But, once women were nominated for several different public offices, most of them took it really hard to get the choice. The magazine "Woman Citizen" published an extensive analysis of the successes and failures of women candidates in the early twenties. The magazine even asked candidates to suggest reasons for their victories or defeats. Although a variety of reasons was given, repetitively almost all of them claimed that they had to overcome the handicap of being women.

There was also a rather striking fact with the candidates to Congress Winifred Lufkin (Massachusetts) and Helen Statler (Michigan). Both nominated by the Republican Party in clearly Republican districts, they both lost the 1920 elections because male voters of their own party chose a Democratic man as a representative to Congress rather than a woman of their own party. The opposition for a woman to reach an agreement in salary and in the position of a man was still too stiff, and not all party colleagues were willing to take the risk.

Another significant example was made up by Ruth H. McCormick, who when opting for Congress by the state of Illinois in 1928, was quite surprised by the vehemence of the resistance of her candidacy for the mere fact of being a woman. In an anonymous letter she received from a voter, it was affirmed: "I would not think to vote for a woman to Congress more than one of my cows for that position of responsibility" [27]. Neither her own friends were very determined to support her because they felt she had no chance of succeeding.

A bit later, when she won the Republican nomination for the Senate, many politicians were alarmed by the idea of a woman in the Senate, despite the number of women who had served in the House of Representatives. Hiram Johnson, travelling companion of Teddy Roosevelt in 1912, made the following statement: "It is quite true that the Senate may not have been sensitive to the traditions of the past few years, but it is by breaking them which will lead to the admission of the other sex to the Senate" [28].

Moreover, almost all the women elected stated that the men who worked with them were quite friendly and hospitable towards them. When historian Sophonisba Breckinridge [29] investigated women state legislators, most of them said that their legislative experience was quite interesting and rewarding.

However, at the same time, many still perceived that women were used as labor policy by male leaders and that they were given little positions with effective or real power. And certainly, there were many cases of discrimination in finding that they did not have sufficient political skills.

\section{Conclusions}

The US politics changed significantly with the mere presence of women in the same and their entrance in all areas of government (local and federal), something just unthinkable a decade ago. The different political interests as well as the style introduced in politics by the first women legislators made citizens change their formed image of politics and politicians. 
In the years before women's suffrage, politics continued to be associated with men and masculine virtues, but the introduction of the XIX Amendment did much to erode this lifetime connection. Perhaps the most noticeable changes had to do with the impact that women voters had on the electoral process itself, in the places where they voted, their behavior, and above all, the meaning given to the voting process. The places where it was traditionally voted (barbershops and taverns) saw as new locations (schools and churches) occupied their hitherto privileged place. Elections held in a school or church gave the vote itself the character of a dignified civic institution.

The image of both political parties and politics itself changed during the decade. It ceased to be unthinkable that women could speak at national conventions, attend party meetings, or be submitted for public office. However, the number of women in positions of real power in the parties and in politics was still small. Yet, boundaries were changed. Just as women were increasingly introduced in hitherto male occupations and professions due to changes in society, women's positions in the federal and national politics were opened to them after the vote.

As the presence of women in Congress and the federal government became more usual, we come to the point of finding some women of a flawless and impressive political stature such as Molly Dewson, Edith N. Rogers, Frances Perkins or Eleanor Roosevelt. However, most experts assume that the political success of women's groups declined during the last years of the decade. Part of the justification can be found in the fact that politicians discovered that women, like men, were divided and therefore the initial fear of the actions of a unified bloc of women was unfounded.

Women legislators in the twenties were influenced by the party leadership and its members when making decisions but their primary revenue revolved around which benefit they could get by and for their constituency. For that reason, women voters were mobilized and attracted by both parties, which made quite unlikely that women's groups organized in favor or against a particular candidate.

There can be little doubt that both men and women perceived that they were quite different politically and thought that women had different political preferences. Members of Congress of the twenties, following a few rules to make decisions based on the possible electoral consequences, took into account women in a way to which they were unaccustomed. This could be checked on in situation in which organized women assumed a position in common.

Any detailed study on the political activity of women from the twenties clearly reveals the critical role that women played in the political life of the country. Women have been the backbone in a process by which federal and local governments assumed greater responsibility for the welfare of their fellow citizens.

In addition, the efforts of association and women's groups, as well as the action of the first women lawmakers, helped transform government and politics, although both men and women were resisted to the idea of extending the conventional understanding of the policy.

In the twenties, both men and women were actively involved in politics but used different forms and political strategies in their ways and means. Gender boundaries that define the behavior in the public sphere completely changed during the decade. As more women were elected to Congress, the notion of citizens of what a politician was radically changed.

Once women entered active politics, despite their rather limited power and number, they highlighted issues that had driven the female's work for many years. In fact, it was considered that women had little political ambition in a conventional sense and were motivated by topics based on their own interests.

For the first time, it was felt that women were potentially a distinct group with a different political agenda and with different political preferences. However, this potential seemed to wane as the decade progressed. The presence of women in Congress made possible a transformation of party politics in the XIX century to the policy based on interest groups and candidates that characterized both the XX and XXI centuries.

\section{References}

[1] Adams, M. (1932) What Are Women Mayors Doing. American City, 26, 543.

[2] Geraldine Anne Ferraro (1935-2011) Was an American Attorney, a Democratic Party Politician, and a Member of the United States House of Representatives. She Was the First Female Vice Presidential Candidate Representing a Major American Political Party.

[3] Miller, L.K. (1921) Woman Citizen, 18 June 1921, 8.

[4] Darcy, R., Welch, S. and Clark, J. (1987) Women, Elections and Representation. Longman, New York, 2. 
[5] Cott, N. (1987) The Grounding of Modern Feminism. Yale University Press, New Haven, 100.

[6] Woman Citizen, 2 August 1919, 210.

[7] Breckinridge, S. (1933) Women in the Twentieth Century. McGraw-Hill, New York, 295.

[8] Sumner, H.L. (2009) Equal Suffrage. Bibliographical Centre for Research, New York, 147.

[9] Nellie Tayloe Ross (1876-1977) Was an American politician, the 14th Governor of Wyoming from 1925 to 1927. She Was the First Woman to Be Elected Governor of a US State. To Date, She Remains the Only Woman to Have Served as Governor of Wyoming. She Was a Staunch Supporter of Prohibition during the 1920s.

[10] Miriam "Ma” Ferguson (1875-1961) Was the First Female Governor of Texas in 1925. She Held Office until 1927, Later Winning Another Term in 1932 and Serving until 1935.

[11] Jensen, J.M. (1981) Disfranchisement Is a Disgrace: Women and Politics in New Mexico, 1900-1940. New Mexico Historical Review, 56, 25.

[12] Clark, I.C. (1929) Feminists Made Gains in Many Fields in 1928. The New York Times, 17 February 1929, 8.

[13] Breckinridge, S. (1933) Women in the Twentieth Century. McGraw-Hill, New York, 317.

[14] Moncure, D. (1929) Women in Political Life. Current History, 29 January 1929, 640.

[15] Allen, F.E. (1947) Participation of Women in Government. Annuals of the American Academy of Political and Social Science, 251, 94-103. http://dx.doi.org/10.1177/000271624725100113

[16] Gordon, F.D. (1947) After Winning: The New Jersey Suffragists, 1910-1947. PhD Thesis, Rutgers University of the State University of New Jersey, New Jersey, 386.

[17] Breckinridge, S. (1933) Women in the Twentieth Century. McGraw-Hill, New York, 332.

[18] Darcy, R., Welch, S. and Clark, J. (1987) Women, Elections and Representation. Longman Press, New York, 9.

[19] Breckinridge, S. (1933) The Activities of Women Outside the Home. McGraw-Hill, New York, 744.

[20] Merriam, C.E. (1979) The American Party System. MacMillan, New York, 29.

[21] Saint, A.M. (1931) Women in the Public Service: General Survey. Public Personnel Studies, 8, 53.

[22] Huus, R. (1930) Cleveland Women in Government and Allied Fields. National Municipal Review, 19, 88-92. http://dx.doi.org/10.1002/ncr.4110190204

[23] Gruberg, M. (1968) Women in American Politics. Academia Press, Oshkosh, 201.

[24] Olesen, D. (1922) Woman Citizen, 2 December 1922, 12.

[25] Search, M. (1922) Women’s Rights in Wisconsin. Marquette Law Review, 6, 164.

[26] Gruberg, M. (1968) Women in American Politics. Academia Press, Oshkosh, 30.

[27] Miller, K. (1992) Ruth Hanna McCormick: A Life in Politics. University of New Mexico Press, Albuquerque, 189.

[28] Miller, K. (1992) Ruth Hanna McCormick: A Life in Politics. University of New Mexico Press, Albuquerque, 223.

[29] Breckinridge, S. (1933) Women in the Twentieth Century. McGraw-Hill, New York, 330. 